\title{
Coexistence of Papillary Thyroid Cancer and Primary Hyperparathyroidism: Report of Five Cases
}

\author{
Hasan Calis1, Nuraydin Ozlem² and Serif Melih Karabeyoglu²
}

\begin{abstract}
Coincidence of primary hyperparathyroidism and thyroid nodules is quite frequent. This is challenging for clinical diagnosis and treatment. We reviewed the records of patients who underwent surgery for primary hyperparathyroidism. Among 52 such cases, thyroidectomy was performed in seven patients $(13 \%)$ at the same time. Papillary thyroid cancer was detected in five patients $(9.6 \%)$ as a result of pathologic examination. Two patients were diagnosed with unifocal micro-papillary cancer and these patients underwent unilateral thyroid lobectomy. The remaining three patients, who had thyroid papillary cancer underwent bilateral total thyroidectomy. Likelihood of thyroid cancer should be considered in cases of primary hyperparathyroidism with coexistent thyroid nodules, and a detailed examination should be performed in preoperative period. These will lead to reduce morbidity and lower cost resulting from a second surgery.
\end{abstract}

Key Words: Thyroid cancer, Hyperparathyroidism, Micropapillary cancer.

\section{INTRODUCTION}

Primary hyperparathyroidism is the most common cause of hypercalcemia. Coincidence of primary hyperparathyroidism and thyroid nodules is quite frequent; the rate varies from $12 \%$ to $52 \%$. This is challenging for clinical diagnosis and treatment. ${ }^{1}$

Limited number of cases have been reported in literature on coincidence of primary hyperparathyroidism and thyroid cancer. Therefore, it requires further investigation. We, herein, describe our experience of cases which were detected to have thyroid cancer among patients who underwent surgery for primary hyperparathyroidism.

\section{CASE REPORT}

Records of patients who underwent surgery for primary hyperparathyroidism at Ahi Evran University Research and Training Center between November 2014 and June 2017 were evaluated retrospectively. Patients who underwent thyroidectomy at the same time and were reported as a result of the final pathology as thyroid cancer were included in the study. Patients with parathyroidectomy due to prior parathyroid adenoma, with MEN (Multiple endocrine neoplasia) syndrome, and under 18 years of age were not included in the study.

Preoperative cervical ultrasonography and $99 \mathrm{~m}$ Tc-MIBI (methoxyisobutylisonitrile) scan were performed in all

1 Department of General Surgery, Faculty of Medicine, Alanya Alaaddin Keykubat University, Alanya-07400, Turkey

2 Department of General Surgery, Faculty of Medicine, Ahi Evran University, Kirsehir-40000, Turkey

Correspondence: Dr. Hasan Calis, Department of General Surgery, Faculty of Medicine, Alanya Alaaddin Keykubat

University, Alanya-07400, Turkey

E-mail:drhasancalis@hotmail.com

Received: August 07, 2018; Accepted: December 18, 2018 patients. Ultrasound-guided fine needle aspiration biopsy (FNAB) was performed in case of suspicion of malignancy. Pathological assessment was done in accordance with Bethesda classification. Intraoperative frozen section pathologic examination was done in the course of the excision of parathyroid adenoma for patients who were suspected to have thyroid carcinoma. Thyroidectomy was performed in patients with the pathology result of malignancy or suspicious for malignancy. Informed consent was obtained from all patients in the preoperative period.

A total of 52 patients were operated with diagnosis of primary hyperparathyroidism. Among them, thyroidectomy was performed in seven patients $(13 \%)$ at the same time. Among these, papillary thyroid cancer was detected in five patients (9.6\%) as a result of pathology examination. Four patients were females and one was male.

Two patients were diagnosed with unifocal micropapillary cancer and these patients underwent unilateral total thyroidectomy (microcancer diameter was 0.40 and $0.48 \mathrm{~mm}$ ). Preoperative FNAB result was reported as colloid and benign follicular cells. The remaining three patients, who had thyroid papillary cancer, underwent bilateral total thyroidectomy. Patient characteristics are presented in Table I. No patients had metastasis.

Case 1: A 42-year female patient had parathyroid and thyroid pathology. A unilateral $9 \mathrm{~mm}$ microcalcifed nodule was detected on ultrasonography. FNAB result of thyroid nodule was reported as colloid and benignappearing follicular cells. Parathyroid adenoma excision and unilateral thyroid lobectomy was performed as the frozen section pathologic examination was reported as malignant (Papillary thyroid microcarcinoma, tumor diameter $0.40 \mathrm{~mm}$ and unifocal). No additional surgery was performed. 
Table I: Demographic, radiological and pathological characteristics of patients

\begin{tabular}{|c|c|c|c|c|c|c|c|c|}
\hline Patient & Gender & $\begin{array}{l}\text { Age } \\
\text { (years) }\end{array}$ & $\begin{array}{l}\text { Focality of } \\
\text { tumour }\end{array}$ & FNAB* $^{*}$ & FSPE** & $\begin{array}{l}\text { Final thyroid } \\
\text { pathology }\end{array}$ & $\begin{array}{l}\text { Parathyroid } \\
\text { pathology }\end{array}$ & USG ${ }^{\star \star \star}$ \\
\hline 1 & Female & 42 & Unifocal & $\begin{array}{l}\text { Colloid and benign- } \\
\text { appearing follicular cells }\end{array}$ & Malignant & $\begin{array}{l}\text { Papillary thyroid } \\
\text { microcarcinoma }\end{array}$ & Adenoma & $\begin{array}{l}\text { Unilateral } 9 \mathrm{~mm} \\
\text { microcalcified nodule }\end{array}$ \\
\hline 2 & Female & 76 & Unifocal & $\begin{array}{l}\text { Benign appearing } \\
\text { follicular cells }\end{array}$ & Malignant & $\begin{array}{l}\text { Papillary thyroid } \\
\text { microcarcinoma }\end{array}$ & Adenoma & $\begin{array}{l}\text { Unilateral } 8 \mathrm{~mm} \\
\text { microcalcified nodule }\end{array}$ \\
\hline 3 & Male & 32 & Bifocal & $\begin{array}{l}\text { Atypia of undetermined } \\
\text { significance }\end{array}$ & $\begin{array}{l}\text { Suspected } \\
\text { malignancy }\end{array}$ & $\begin{array}{l}\text { Papillary thyroid } \\
\text { carcinoma }\end{array}$ & Adenoma & $\begin{array}{l}14 \mathrm{~mm} \text { hypoechoic } \\
\text { microcalcified nodule }\end{array}$ \\
\hline 4 & Female & 48 & Multifocal & Malignant & None & $\begin{array}{l}\text { Papillary thyroid } \\
\text { carcinoma }\end{array}$ & Adenoma & $\begin{array}{l}\text { Nodule with } 20 \mathrm{~mm} \text { hypoechoic } \\
\text { peripheral calcification }\end{array}$ \\
\hline 5 & Female & 50 & Multifocal & Malignant & $\begin{array}{l}\text { None } \\
\text { carcinoma }\end{array}$ & Papillary thyroid & Adenoma & $\begin{array}{l}\text { Nodule with } 15 \mathrm{~mm} \\
\text { hypoechoic peripheral } \\
\text { calcification }\end{array}$ \\
\hline
\end{tabular}

${ }^{*}$ FNAB: Fine needle aspiration biopsy; $\quad{ }^{* *}$ FSPE: Frozen section pathologic examination; ${ }^{* \star \star} U S G$ : Ultrasonography.

Case 2: A 76-year female patient presented with dual parathyroid and thyroid pathology. A unilateral $8 \mathrm{~mm}$ microcalcified nodule was detected on ultrasonography. FNAB result of thyroid nodule was reported as benign appearing follicular cells. Parathyroid adenoma excision and unilateral thyroidlobectomy was performed as frozen section pathologic examination was reported as malignant (Papillary thyroid microcarcinoma, tumor diameter $0.48 \mathrm{~mm}$ and unifocal). No additional surgery was performed.

Case 3: A 32-year male patient was diagnosed with both parathyroid and thyroid pathology. A hypoechoic microcalcified $14 \mathrm{~mm}$ nodule was detected on ultrasonography. FNAB result of thyroid nodule was reported as 'atypia of undetermined significance'. Parathyroid adenoma excision and bilateral total thyroidectomy was performed as frozen section pathologic examination was reported as suspicious for malignancy. The final pathologic examination showed a bifocal papillary thyroid carcinoma.

Case 4: A 48-year female patient presented with both parathyroid and thyroid pathology. A nodule with $20 \mathrm{~mm}$ hypoechoic peripheral calcification was detected on ultrasonography. FNAB result of thyroid nodule was reported as malignant. Parathyroid adenoma excision and bilateral total thyroidectomy was performed. The final pathologic examination showed multicentric papillary thyroid carcinoma.

Case 5: A 50-year female patient presented with dual parathyroid and thyroid pathology. A nodule with $15 \mathrm{~mm}$ hypoechoic peripheral calcification was detected on ultrasonography. FNAB result of thyroid nodule was reported as malignant. Parathyroid adenoma excision and bilateral total thyroidectomy was performed. The final pathologic analysis revealed multicentric papillary thyroid carcinoma.

\section{DISCUSSION}

Previous studies have shown that some cancers, like hematological, breast and urinary system malignancies are common in patients with primary hyperparathyroidism. ${ }^{2}$ Coexistence of parathyroid adenoma and thyroid cancer has been reported with a wide range (3\%-70\%). In these patients, thyroidectomy was performed concurrently with parathyroid adenoma excision in $13 \%$ of the cases. Thyroid cancer was detected in $9.6 \%$ of patients as a result of pathologic examination. The wide range of prevalence may be reflective of varying as diagnostic methods, indications for surgery and differences between patient selection criteria. 3,4 In the light of these data, the question arises that "Is primary hyperparathyroidism a risk factor for thyroid cancer?" Primary hyperparathyroidism is not considered as a risk factor for thyroid cancer in American Thyroid Association (ATA) guideline. 5 The wide range of the coexistence of parathyroid adenoma and thyroid cancer (3\%-70\%) nullifies the hypothesis that parathyroid adenoma is a risk factor for thyroid cancer. Prospective studies conducted on large number of patients are required for better understanding the relationship of hyperparathyroidism with thyroid cancer.

FNAB is widely used for diagnosis of malignancy in thyroid nodules. FNAB may yield false negative results in nodules smaller than $10 \mathrm{~mm}$; although, it is the most valuable diagnostic tool for papillary thyroid cancer. 6,7 In a study, almost $39 \%$ of thyroid cancers were shown to be $10 \mathrm{~mm}$ or smaller. In addition, regional lymph node metastasis was reported in $1.6 \%-3.3 \%$ of the patients who had nodules measuring $6-10 \mathrm{~mm} .8$

In case of suspicion, ultrasound-guided FNAB should be performed for nodules smaller than $10 \mathrm{~mm} .^{5}$ Indications for FNAB were used according to ATA 2015 guidelines in these patients' group. Thyroid nodules were smaller than $10 \mathrm{~mm}$ in only two patients $(8$ and $9 \mathrm{~mm})$ and microcalcifications were detected. In both FNAB results, it was reported as benign. Unilateral thyroid lobectomy was performed as frozen section pathologic examination was reported as malignant (tumor diameter, 0.40 and $0.48 \mathrm{~mm}$ and unifocal). No additional surgery was performed as tumor diameter was 0.40 and $0.48 \mathrm{~mm}$. Lobectomy alone is sufficient, if history of head and neck surgery, familial thyroid carcinoma or clinically detectable lymph node metastasis are not present in small, unifocal intra-thyroidal carcinomas. ${ }^{5}$ 
Preoperative FNAB should be performed in patients with primary hyperparathyroidism, who have thyroid nodules smaller than $10 \mathrm{~mm}$, if there is risk of malignancy according to ultrasonography findings. Intraoperative palpation of thyroid nodule and frozen section pathologic examination should be done even if FNAB result is benign. Serious problems may be encountered, if diagnosis of thyroid cancer is overlooked in cases of coexistence of parathyroid adenoma and thyroid cancer. Recurrent laryngeal nerve injury and hypoparathyroidism, which may result from a second surgical intervention, are the most important complications.

\section{REFERENCES}

1. Murray SE, Sippel RS, Chen H. Incidence of concomitant hyperparathyroidism in patients with thyroid disease requiring surgery. J Surg Res 2012; 178:264-7.

2. Nilsson IL, Zedenius J, Yin L, Ekbom A. The association between primary hyperparathyroidism and malignancy: Nationwide cohort analysis on cancer incidence after parathyroidectomy. Endocr Relat Cancer 2007; 14:135-40.

3. Regal M, Páramo C, Luna Cano R, Pérez Méndez LF, Sierra JM,
Rodríguez I, et al. Coexistence of primary hyper-parathyroidism and thyroid disease. J Endocrinol Invest 1999; 22:191-7.

4. dell'Erba L, Baldari S, Borsato N, Bruno G, Calò-Gabrieli G, Carletto $\mathrm{M}$, et al. Retrospective analysis of the association of nodular goiter with primary and secondary hyperparathyroidism. Eur J Endocrinol 2001; 145:429-34.

5. Haugen BR, Alexander EK, Bible KC, Doherty GM, Mandel SJ, Nikiforov YE, et al. 2015 American thyroid association management guidelines for adult patients with thyroid nodules and differentiated thyroid cancer: The American thyroid association guidelines task force on thyroid nodules and differentiated thyroid cancer. Thyroid 2016; 26:1-133.

6. Hambleton C, Kandil E. Appropriate and accurate diagnosis of thyroid nodules: A review of thyroid fine-needle aspiration. Int $\mathrm{J}$ Clin Exp Med 2013; 6:413-22.

7. Shrestha M, Crothers BA, Burch HB. The impact of thyroid nodule size on the risk of malignancy and accuracy of fineneedle aspiration: A 10-year study from a single institution. Thyroid 2012; 22:1251-6.

8. Roti E, Rossi R, Trasforini G, Bertelli F, Ambrosio MR, Busutti L, et al. Clinical and histological characteristics of papillary thyroid microcarcinoma: Results of a retrospective study in 243 patients. J Clin Endocrinol Metab 2006; 91:2171-8. 